\title{
Influence Of Corporate Social Responsibility in Building Organization Attractiveness Among Individual Employees
}

\author{
Menaga.A ${ }^{1}$, Dr.S.Vasantha ${ }^{2^{\star}}$ \\ ${ }^{1}$ PhD Scholar, School of Management Studies, Vels Institute of Science \& Technology \& Advanced Studies (VISTAS) \\ Email: Menagalokesh@gmail.com \\ ${ }^{2}$ Professor, School of Management Studies, Vels Institute of Science \& Technology \& Advanced Studies (VISTAS) \\ Email: vasantha.sms@velsuniv.ac.in \\ ${ }^{*}$ Corresponding Author
}

Received: 06.08.2021

Accepted: 17.08.2021 Published: 02.10.2021

DOI: $\underline{10.47750 / Q A S / 22.184 .32}$

\begin{abstract}
Organizations are obligated to provide Corporate Social Responsibilities to the society share their profitable, in developing the society or where ever there is a requirement for the need for developments. Likewise, CSR activities also help in improving the Employer and Employee relationship on enhancing their work culture which leads to productive output, this also helps in a win-win situation for achieving the organization goals. The purpose of the research is to study the influences of corporate social responsibility activities in creating the organization attractiveness (OA) among individual employees. The research is to identify and evaluate the attractiveness the CSR created towards the employees. At the same time to address the gap in creating OA. The Research developed the $A B C E$ model (cognitive, affective, behavioural, new effective rational belief) to assess the individual attractiveness among employees. The structure is grounded with The integration of two models cognitive behavioural therapy (CBT) and Rational emotive behaviour therapy (REBT Ellis, 1957). Research conducted the empirical study in India collecting data among corporate employees - greatly profound towards CSR subjects. The research identifies that implementation of correct/suitable CSR activities creates attractiveness to the employees towards their organization.
\end{abstract}

Keywords: Brand awareness, corporate social responsibility, cognitive behavioural therapy, Employees, Employer, Organization attractiveness

\section{Introduction}

Corporate social responsibility communication plays a vital role in playing organization or employer attractiveness (McElhaney, 2008) But there is very less attention given to CSR Performances and ethical of the organization during employees selection (Backhaus, 2004), it's an important role for the organization to communicate about the CSR activities, which will create employer attractiveness among employees and job seekers (Alniacik et al., 2011).

CSR is a powerful tool which will create both Positive and negative impact among employees (Dobers and Springett, 2010), the research depicts whether a good CSR activity attract the potential employees for the organization (Friedman, 1970). The millennial shows the greatest interest in organizational moral activities (Connell et al., 2012)Also the young generation who is born before 1997 beliefs that's corporate with greater moral value creates an environment better (Cone 2006). In this content the employees believe the organization with good moral value where they are working will add their efforts, this will creates an organization attractiveness at large where they want to work

The purpose of the research is to assess how corporate employee's attitude influence the employees with CSR activates done by the organization which creates organization attractiveness therefore the researchers propose the following research question. How do Corporate employees attitude towards CSR activates inspires CSR based OA? (Corporate social responsibility creates organization attractiveness) The research intended to address the link between the CSR performances of the organization and how that will create an organization attractiveness which is known as CSR based OA, the research used quantitative analysis collected data from 200 corporate employees who are highly sensitive towards corporate issues, that is the data are collected from employees who are voluntary in the CSR initiative done by the organization, research analyses the gap in creating CSR based $\mathrm{OA}$ and introduce the new rational belief variable as a mediator to increase the organization attractiveness.

\section{Csr And Organization Attractiveness}

The job seekers and employees of the organization has a Positive image towards an organization (Lin et al., 2016) Employees will support and peruse the organization for The long run which supports the environment (Greening and 
Turban, 2000) The factor measures to calculate the CSR based $O A$ are demographic profile such as age, gender and other factors like knowledge towards the organization (Freeman, 2000)

Employees who involve in CSR performances done by the organization like working with NGO, helping local communities like fixing infrastructure etc which the employees will have a stronger emotional connect with the organization also they have a personal belief towards the CSR itself According to (Livens \& High house, 2003) the organization branding involves factors like Instrumental factor which is the personal benefit of the employee like payroll, bonus and symbolic factor is like a stronger connection between employer and employee creates greater OA (Chatman, 1989). Likewise the study explores how individual employees get influenced by CSR based OA by reviewing social identity theory and personal organization fit approach

\section{Individual Attitudes to Csr}

Individual attitude towards CSR is based on organization policy and procedure evaluation and belief on the CSR performances (Ajzen and Cote, 2008, p. 289). The CSR in the research is treated as psychological accepts which is known as the ABC approach (affective, behavioural factor and cognitive) which is also known as CSR dimensions (Aronson et al., 2009). The cognitive is measured with two scales one is instrumental where the belief of the employees is like CSR is done by the organization only for profit maximization another one is normative it implies CSR is done by an organization with good intention to create a change in society (Basu and Palazzo 2008)The next factor is social, which measures the individual employees interest towards organization social activity this has two scale measure High/low Kleinrichert et al., 2013) and willing to involve in CSR activities (Bosque, 2015) Lastly affective factor which asses the Postive and negative image towards employs Positive image like trustworthy, feeling negative image can be self-profit making organization

By asseing all these factors the research address the gap in organization attractiveness among employees by introducing mediating factor "new rational belief", the gap can be addressed by creating awareness among employees the major break is created because of lack of information and awarness created by the organization, to discourse these break the research evaluated the latest updated of CSR communication done by top ten CSR performing organization in india social media, broachers' and website and see if there is CSR communication is up-to-date and transparent for employees to access

\section{Employees Attitudes Towards with Csr- Based Organization Attractiveness}

Organization fresher's shows a greater sense of interest towards CSP (Connell et al., 2012)Employee's try's to connect their values and organization values (Jones et al., 2014)So if the employees try to find a link they find the job more attractive day to day and hence creates CSR based OA (Backhaus et al., 2002). (Jones et al. 2014) explains how CSP creates an OA he categorized three thing sense of pride in affiliating in the organization, how the organization treats the employees and interest

Whereas (Ulrich, 2015) says the employees look corporate value then CSR. The term CSR is understood differently by an individual, so the measurement itself is very complicated, the higher value the individual gives towards the CSR the greater attractiveness among organization will take place, so therefore

$\mathrm{H} 1$; Positive attitude towards CSR from employees creates, greater their CSR-based OA

The hypothesis is subcategorized into three dimensions of CSR based OA is analysed that affective, behavioural, cognitive According to (Donaldson, 1995) cognitive dimension is asses with instrumental and normative, whereas the employees who instrumentally see the organization sees CSR is done for profit bases will have less OA will not get much attraction towards an organization like the employees who perceives in a normative way (Tsai et al., 2014), therefore the employees who show greater ethical and social responsibility for the business operation has an organization attractiveness.

$\mathrm{H} 1 \mathrm{a}$-Employees who recognize CSR in a normative way shows the Positive CSR based OA

The second sub categorization is an affective dimension which represents the employees Positive and negative emotional attachment (Onkila, 2015). Study approves that CSP shows the organization a Positive influence (Vlachos, 2012). Whereas the negative perception towards CSR will create a bad image among individual employees (Olsen et al.2006).therefore

H1b Employees who Positively analyze CSR shows the greater CSR based OA than those who negative analyze

Lastly, the behavioural dimension is each employee attitude towards CSR. Many studies have confirmed the importance of social performances of organization for employees liking towards business (Tsai et al., 2014). It represents the greater readiness to work in the organization. The employee who find the greater value in the organization which aliens his core belief he will treat himself a responsible for organization development (Bricks on, 2007). Hence Employees who display greater involvement in CSR will show the greater CSR based OA than those who show low involvement

H2c. employees who show a high engagement with CSR will show a

Higher CSR-based EA than those who show a low engagement with CSR

\section{New Effective Self Belief}

This phase is also called as Positive reinforcement phase (Ellis \& Dryden, 1997). When the employees are not normative or negative or who has low involvement in CSR factor involves various factors, the research adopts the rational ling the belief by creating awareness. The new effective rational belief is adopted from REBT theory (Ellis, 1957) The first take of the REBT is self-working by providing Homework tasks (Wolfe, 1958) the organization should conduct the periodical assessment from employees to find attractive, for the person with low involvement and negative impact in Csr performances can create self-awareness among by asking to explore organization website, broachers' and social media them, and reassessment should be done among employees challenging situations (Froggatt, 2005). but important accept to do this firstly the organization should be updated with the CSR Communication, to analyze this top ten CSR performing organization is select (Shree Cements Ltd, Dalmia Bharat GroupTata Motors Ltd.Hindalco Industries Ltd.Reliance Industries Ltd.Tata Steel Ltd. Adani Power Ltd. Hindustan Petroleum Corporation Ltd. Hindustan Petroleum Corporate Ltd) assessment is made CSR Communication is done by selected organisation Frequently

$\mathrm{H} 2$-Reinforcing new effective rational belief can create greater attractiveness 


\section{Conceptual Framework}

Figure 1 shows the conceptual model of the study. The study adopted cognitive behavioural therapy (CBT) and rational emotive behaviour therapy (REBT Ellis, 1957). The research study is extended the Corporate social responsibility based organization model which is also called the "CSR-ABCE based OA "model for assessing the individual employee's attractiveness towards the organization and address the gap by introducing mediating variable called new effective rational belief among the employees

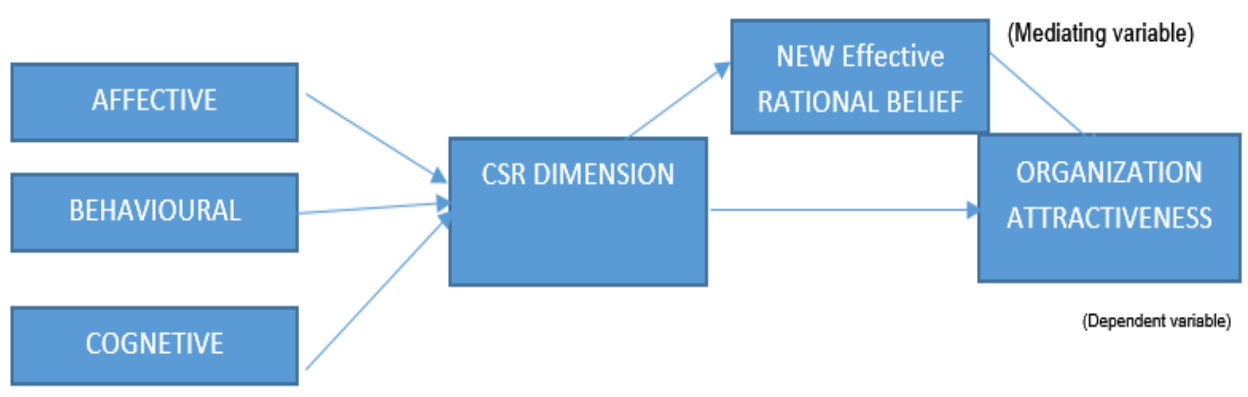

(Independent variable)

FIG -1 CSR ABCE based OA model

Figure 1: Corporate social responsibility based organization attractiveness

CSR-corporate social responsibility, ABCE-affective, behavioural, cognitive, $O A$-organization attractiveness

\section{Methods}

The author explored psychology dimension like affective, behavioural and cognitive and new effective social belief which is an extension of the CBT model .quantitative approach is used first to determine the CSR based OA with multiple regression, second Hayes process is used to find the Hayes process because to find the direct and indirect effect of direct effect shows how an individual is attracted towards the organization (Tsai and Yang, 2010), indirect effect address the gap of $O A$.

\subsection{Sample}

The study investigates two things, individual employee's organization attractiveness which is called CSR based OA (which is greatly influenced by psychological factor of the employees (Tsai and Yang, 2010), Secondly to analyze the Organization attractiveness after introducing rational thoughts which are self-awareness by exploring CSP of the organization among corporate employees. The data is collected among corporate employees in (India) who are highly sensitive to CSR activities, who involves directly in CSR activities.

Contributors were voluntary and anonymous. 200 valid questionnaires were collected.96 women and 104 male respondent frequency of age group are under age group -36 members are under 15-25, 58 wherein age group between 26 35,46 members are between $36-45,42,18$ respondents are in the age group of $46-55$, above 56 , likewise, the education levels are measured school, graduated level are 14,77 respondent, whereas postgraduate and other educators are 64,45

\subsection{Measures}

Firstly the study evaluates employees attitude towards CSR based Organization attractiveness which is measured into $A B C$ dimension affective behavioural and cognitive) the questionnaire is adopted by (Klimkiewicz \& Oltra, 2017) which were measured. The cognitive CSR is measured with a fivepoint Likert scale where one is instrumental and five is normative, which measures the individual employee's attitude whether (instrumentals or normative). The cognitive aspect of CSR examines the factors like equality reliability, profitmaking, legal obligation, social goals and environmental behaviour (Aiman-Smith et al., 2001, Smith and Langford, 2011)

Secondly, the affective dimension is measured, which states the individual feeling among organization CSR performances (Karnani, 2010; Smith, 2003). The third is individual involvement in CSR which asses the behavioural dimension, it includes volunteering activities in the local community, and willingness to deepen the knowledge in social issue Cone Communications, 2006) for measuring affective and behavioural Likert scale is used (1-strongly disagree, 5strongly agree)

Lastly, New effective belief is post Positive reinforcement on creating organization attractiveness, since the study is conducted for the short term the research proposed to test the indirect effect of CSR based OA, here rational belief enforcement is self-learning of CSR with available sources like Social media, Boucher's and website, the variable is measured with Less/more communication, five-point Likert scale is adopted, this is self-constructed method modified by (elies.1995)

\section{Findings}

Hypotheses are tested for adoptive scale, Refer sample ( Appendix )CSR based organization attractiveness with threedimensional independent variable namely CSR normative, CSR Positive and CSR Involvement and second hypothesis is tested to explore the impact of awareness on organization attractiveness by CSR high/low awareness, Reliability test 
(Cronbach's alpha) is done for all the variable, normative dimension is 0.91 , CSR Positive is 0.85 , for CSR involvement it's 0.86 , CSR awareness its 0.869 , all the variables are above 0.8 , Ref Table -1

Table 2, shows the correlation among variables from the hypothesis, all the items are correlated (Nunnally, 1978) all the value are above $0.5, \mathrm{~N}=200$, Multivariate assessment is done on $\mathrm{H} 1 \mathrm{a}, \mathrm{H} 1 \mathrm{~b}$ and $\mathrm{H} 1 \mathrm{c}$. multiple linear regressions were plotted here the influence that millennial job seekers' attitudes towards

CSR might have on CSR-based EA was tested, the overall adjusted $R$ Square value is 0.92 , overall $F$ Value is 844.111 and significant is $<0.05$ it shows our model is a good fit, shows over hypothesis for Positive attitude towards CSR from employees creates, greater their CSR-based OA is accepted

With $\mathrm{H} 1$ a Employees who recognize CSR in a normative way shows the Positive CSR based $\mathrm{OA}(\mathrm{B}=0.65, \mathrm{P}<0.5)$ which is statistically significant, which shows employees with greater normative perception towards organization has a Positive impact among the organization,

H1b Employees who Positively analyze CSR shows a greater CSR based OA than those who negative analyze based on the hypothesis $(B=.533, p<0.05)$ significant, $H 2 c$. employees who show a high engagement with CSR will show a Higher CSR-based EA than those who show a low engagement with $C S R,(B=.722, P<0.05)$ is significant which shows a person who gets personally involved in the CSR has a sense of strong relationships among employer, lastly $\mathrm{H} 2$ Reinforcing new effective rational belief can create greater attractiveness was tested using Hayes process Direct effect amid Awareness (new effective rational belief) and Corporate social responsibility dimension (Cognitive, affective, behavioural) is significant $(b=0.51$, $s e=0.07 . p=0)$ the outcome implies that Corporate social responsibility increases the organization attractiveness, The direct effect between Awareness and organization attractiveness is positive $(b=0.54$, $\mathrm{se}=0.09, \mathrm{p}=0$ ) which specifies awareness impact directly on organization attractiveness, whereas The indirect effect is a test using Bootstrapping. The indirect effect $(\mathrm{IE}=0.72)$ is significant at $\mathrm{Cl}=(0.065 ., 0.72)$, which shows when Employees is created with a sense of awareness of what the organization is doing will create strong CSR based organization attractiveness.

\section{Discussion}

The Research shows there is an individual employee from the organization do get attracted, with the organization which does CSR, the research is supported with past study (Jones et al., 2014, Turban, 2000). The Positive attributes towards CSR created CSR based OA, the result indicates from all the three dimensions of CSR states employees sustain an organization more when an organization is obligated with corporate social performances Rayton et al. (2015) Where CSP is considered as a psychological aspect of employees.

The result shows the employees considered more on the effective and behavioural dimension, and employees are giving litter importance's for normative, this is because only if the organization gains profit, it will be beneficial for employees CSR based $O A$ can be gained when organization keep updating the CSR activities which they perform, the CSR communication can be done in clipboards, small banner and mostly transparent Social media and website, our study assessed the CSR communication done by top-performing in India, the fact that many places the communication is not up to date, this is the situation for top-performing companies, enhancing the communication and creating the awareness of performances can create more attractiveness and potential employees will be achieved in the organization the finding collide with (Basu and Palazzo, 2008)CSR signals creates a good indicator towards employees, this will impact employees Positive on organization attractiveness

\section{Conclusion}

The researchers contribute to understand the individual employee's attitude towards CSR performances of the organization. The novel contribution of the study is introducing "New ration belief" among employees by creating awareness to enriches the attractiveness towards the organization. Research also find out the CSR itself a signal for organization attractiveness.

Traditional CSR is people have to remember the CSR policies and performances and assess the employees. So remembering CSR among individual is an important aspect which is favourable to the organization. This will eradicate the wrong judgement among employees which removes the negative emotions The managers can improve the negative CSR emotions by creating awareness on actually CSR activities, for this indirect influences among employees can be a poster, and banner about CSR activities done by the organization can be displayed in and around office premises As individual employees tend to show much interest in CSR engagement in affective dimension, so the employees must be involved in CSR event and programmes.

The organization's responsibility to make clear about the organization policies and procedure, also the organization focuses on eradicating the gap in actual CSR and CSR plan to attract the employees' trust and image

Finally, the research has its limitation, the study is conducted for employees only future it can test on job seekers with the same factor, secondly, the study measure is only known awareness of CSR communication in rational belief development future the research can be done as a longitudinal study to get a precise Csr based organization attractiveness.

\begin{tabular}{|l|l|}
\hline & Cronbach's Alpha if Item Deleted \\
\hline CSR_Normative & .912 \\
\hline CSR_postive & .855 \\
\hline CSR_engagement & .862 \\
\hline CSR_awarness & .869 \\
\hline
\end{tabular}

Table 1: Reliability Test 


\section{GENERAL MANAGEMENT}

\begin{tabular}{|c|c|c|c|c|c|}
\hline & CSR & Normative & CSR postiv & CSREnga & CSR Awarness \\
\hline CSRI (CSR_Normative) & 1 & 0.63 & & & \\
\hline CSRII (CSR_postive) & & 1 & 0.64 & & \\
\hline CSRII (CSREnga) & & & 1 & 0.69 & \\
\hline \multirow[b]{2}{*}{ CSR choice II(awarness ) } & & & & 1 & \\
\hline & & & & & 1 \\
\hline
\end{tabular}

Table 2: Pearson correlation matrix

\begin{tabular}{|l|l|l|l|l|l|l|l|}
\hline DIRECT EFFECT & $\mathrm{R}$ & $\mathrm{R}-\mathrm{Sq}$ & $\mathrm{MSE}$ & $\mathrm{F}$ & $\mathrm{dfl}$ & $\mathrm{dlf} 2$ & $\mathrm{p}$ \\
\cline { 2 - 8 } & 0.62 & 0.41 & 0.34 & 49.1 & 2 & 147 & 0 \\
\cline { 2 - 8 } & coeff & $\mathrm{se}$ & $\mathrm{t}$ & $\mathrm{p}$ & $\mathrm{ULCl}$ \\
\hline CSR Dimension & 0.51 & 0.07 & 6.1 & 0 & 0.44 & 0.61 \\
\hline Awarness & 0.54 & 0.09 & 7.2 & 0 & 0.16 & 0.53 \\
\hline
\end{tabular}

\begin{tabular}{|l|l|l|l|l|l|l|l|}
\hline $\begin{array}{l}\text { INDIRECT } \\
\text { EFFECT }\end{array}$ & effect & $\mathrm{se}$ & $\mathrm{t}$ & $\mathrm{p}$ & $\mathrm{LICl}$ & ULICI & C_PS \\
\cline { 2 - 7 } & 0.72 & 0.52 & 0.45 & 0 & 0.55 & 0.81 & 0.87 \\
\cline { 2 - 7 } & EFFECT & Bootse & Boost LICI & Boot ULCI & \\
\hline Awarness & 0.65 & 0.09 & 0.92 & 0.72 & & \\
\hline
\end{tabular}

Table 3: Direct and indirect effect Hayes process

Mediation analysis

Model -4

Y-OA (Organization attractiveness)

X-CSR dimension (Corporate social responsibility)

M- Awarness

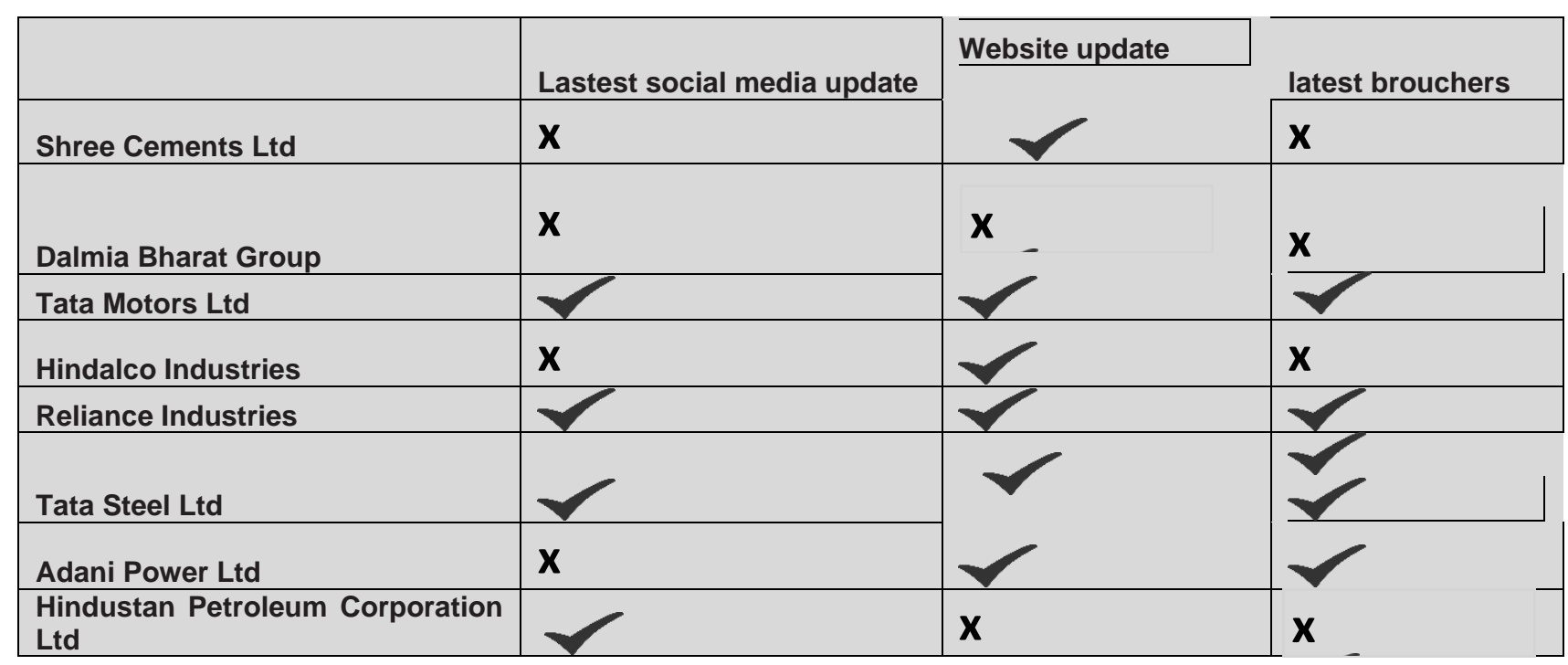

For New rational belief analysis

Table 4: Awarness

\section{References}

[1] Aiman-Smith L, Bauer TN, Cable DM. 2001. Are you attracted? Do you intend to pursue? A Recruiting policy-capturing study. Journal of Business and Psychology 16(2): 219-237. DOI: 10.1023/A:1011157116322

[2] Ajzen I, Cote, NG. 2008. Attitudes and the prediction of behaviour. In Attitudes and attitudeChange. WD Crano, R Prislin (eds.)
Psychology Press: New York: 289-311.

[3] Albinger, H. S., \& Freeman, S. J. (2000). Corporate Social Performance and Attractiveness as anEmployer to Different Job Seeking Populations. Journal of Business Ethics, 28(3), 243-253. doi: 10.1023/a:1006289817941

[4] Alniacik U, Alniacik E, Genc N. 2011. How corporate social responsibility information influences stakeholders' intentions. Corporate Social Responsibility and Environmental Management 18(4): 234-245. DOI: 10.1002/csr.245 
[5] Backhaus, K. B. (2004). An Exploration of Corporate Recruitment Descriptions on Monster.com. Journal of Business Communication, 41(2), 115-136. doi: 10.1177/0021943603259585

[6] Backhaus, K. B., Stone, B. A., \& Heiner, K. (2002). Exploringthe Relationship Between Corporate Social Performance and Employer Attractiveness. Business \& Society, 41(3), 292-318. doi: $10.1177 / 0007650302041003003$

[7] Barrena-Martínez, J., López-Fernández, M., Márquez-Moreno, C., \& Romero-Fernández, P. M. (2014). Corporate Social Responsibility in the Process of Attracting College Graduates. Corporate Social Responsibility and Environmental Management, 22(6), 408-423. doi: 10.1002/csr.1355

[8] Basu, K., \& Palazzo, G. (2008). Corporate Social Responsibility: A Process Model of Sensemaking. Academy of Management Review, 33(1), 122-136. doi: 10.5465/amr.2008.27745504

[9] Baumann-Pauly, D., Wickert, C., Spence, L. J., \& Scherer, A. G. (2013). Organizing Corporate Social Responsibility in Small and Large Firms: Size Matters. Journal of Business Ethics, 115(4), 693-705. doi: 10.1007/s10551-013-1827-7

[10] Cable, D. M., \& Judge, T. A. (1996). Person-Organization Fit, Job Choice Decisions, and Organizational Entry. Organizational Behavior and Human Decision Processes, 67(3), 294-311. doi: 10.1006/obhd.1996.0081

[11] Cable, D. M., \& Turban, D. B. (2003). The Value of Organizational Reputation in the Recruitment Context: A Brand-Equity Perspective. Journal of Applied Social Psychology, 33(11), 22442266. doi: 10.1111/j.1559-1816.2003.tb01883.x

[12] Chatman, J. A. (1989). Improving Interactional Organizational Research: A Model of Person-Organization Fit. Academy of Management Review, 14(3), 333-349. doi: 10.5465/amr.1989.4279063

[13] Ciemniewski W, Buszko M. 2009. Młodzi konsumenci o CSR. Raport z badania ilościowego.Gemius, FOB. http://pliki.gemius.pl/Raporty/2009/2009_11__Mlodzi_konsumenci_o_CSR.pdf [1 July 2016]

[14] Cone, AMP Agency. 2006. The 2006 Cone Millennial cause study. The Millennial Generation: Pro-Social and Empowered to Change the World. http://www.centerforgiving.org/Portals/0/2006\%20Cone\%20Mille nnial\%20Cause\%20Study.pdf [1 July 2016]
[15] Cone Communications. 2006. Civic-Minded Millennials Prepared to Reward or Punish Companies Based on Commitment to Social Causes. CSRwire. http://www.csrwire.com/News/6641.html [8 January 2015]

[16] Randy Evans, W., \& Davis, W. D. (2008). An Examination of Perceived Corporate Citizenship, Job Applicant Attraction, and CSR Work Role Definition. Business \& Society, 50(3), 456-480. doi: $10.1177 / 0007650308323517$

[17] Eweje G, Brunton M. 2010. Ethical Perceptions of Business Students in a New Zealand University: Do Gender, Age and Work Experience Matter? Business Ethics 19(1): 95-111. DOI: 10.1111/j.1467-8608.2009.01581.x

[18] Michailides, T. P., \& Lipsett, M. G. (2012). Surveying Employee Attitudes on Corporate Social Responsibility at the Frontline Level of an Energy Transportation Company. Corporate Social Responsibility and Environmental Management, 20(5), 296-320. doi: 10.1002/csr.1291

[19] Miles, S. J., \& Mangold, G. (2004). A Conceptualization of the Employee Branding Process. Journal of Relationship Marketing, 3(2-3), 65-87. doi: 10.1300/j366v03n02_05

[20] O'Donohue, W., \& Nelson, L. (2009). The Role of Ethical Values in an Expanded Psychological Contract. Journal of Business Ethics, 90(2), 251-263. doi: 10.1007/s10551-009-0040-1

[21] Ohlrich, K. (2015). Exploring the Impact of CSR on Talent Management with Generation Y. South Asian Journal of Business and Management Cases, 4(1), 111-121. doi: $10.1177 / 2277977915574044$

[22] Onkila, T. (2013). Pride or Embarrassment? Employees' Emotions and Corporate Social Responsibility. Corporate Social Responsibility and Environmental Management, 22(4), 222-236. doi: $10.1002 /$ csr. 1340

[23] Pérez, A., \& Rodríguez del Bosque, I. (2014). An Integrative Framework to Understand How CSR Affects Customer Loyalty through Identification, Emotions and Satisfaction. Journal of Business Ethics, 129(3), 571-584. doi: 10.1007/s10551-0142177-9.

[24] Pérez, A., \& Rodríguez del Bosque, I. (2015). Corporate social responsibility and customer loyalty: exploring the role of identification, satisfaction and type of company. Journal of Services Marketing, 29(1), 15-25. doi: 10.1108/jsm-10-20130272 